\title{
The Correlation of Parents' Social Support with Student Achievement in Aqidah Akhlak Subjects
}

\author{
*Jusmeli Hartati ${ }^{1}$ \& Tumin $^{2}$ \\ ${ }^{1,2}$ Universitas Muhammadiyah Yogyakarta, Jl. Brawijaya, Kasihan, Bantul, Daerah \\ Istimewa Yogyakarta, Indonesia \\ *jusme1490@gmail.com
}

\begin{abstract}
This study aims to describe parents' social support with learning achievement in the subject of akidah akhlak (moral theology) at MTsN (Islamic Junior High School) 3 Sijunjung, as well as to see the correlation between parents' social support and learning achievement in the subject of akidah akhlak in students at MTsN 3 Sijunjung. This research is a correlation study using a quantitative approach with descriptive methods. Data were analyzed using descriptive statistics in the SPSS version 21 program and Pearson Product Moment Correlation (r). This study used a quantitative research approach with data collection using observation, questionnaires, and documentation. The research subjects were 138 students of MTsN 3 Sijunjung who were in grade VIII. The results showed that the average value of parents' social support was 66.1667, which means that parents' social permission was at the moderate category level. At the same time, the average value of learning achievement in akidah akhlak subject is 69.8188 at a reasonable level. The results show that the correlation coefficient was 0.428. This means that the strength of the correlation is at an intermediate level. There is a significant correlation between parents' social support and learning achievement in the akidah aklak subject because the significant correlation value is 0.000. This result shows that Ha is accepted and Ho is rejected. So that the greater the parents' social support, the better the learning achievement of the students of MTsN 3 Sijunjung. It is because the results of the coefficient distribution are positive. The finding in this study is that the greater the parents' social support, the better the student's achievement in akidah aklak subject.
\end{abstract}

Penelitian ini bertujuan untuk mendeskripsikan dukungan sosial orang tua dengan prestasi belajar mata pelajaran akidah akhlak di MTsN 3 Sijunjung, serta melihat hubungan antara dukungan sosial orang tua dengan prestasi belajar mata pelajaran akidah akhlak pada siswa di MTsN 3 Sijunjung. Penelitian ini adalah penelian korelasi menggunakan pendekatan kuantitatif dengan metode deskriptif.Data dianalisis menggunakan statistik deskriptif dalam program SPSS versi 21 dan Pearson Product Moment Correlation (r). Penelitian ini menggunakan pendekatan Penelitian kuantitatif dengan pengumpulan data menggunakan observasi, angket dan dokumentasi. Subjek Penelitian adalah 138 siswa MTsN 3 Sijunjung yang sedang kelas VIII Subjek Hasil Penelitian menunjukkan bahwa nilai rata-rata Dukungan sosial orang tua adalah 66,1667 artinya dukungan sosial orang tua di tingkat kategori sedang. Sedangkan nilai rata-rata prestasi belajar mata pelajaran 
akidah akhlak adalah 69,8188 yang berarti prestasi belajar mata pelajaran akidah akhlak di tingkat sedang. Hasil Penelitian menunjukkan nilai koefisien korelasi sebesar 0,428. Artinya kekuatan korelasi berada pada tingkatan sedang. Ada hubungan yang signifikan antara dukungan sosial orang tua dengan prestasi belajar mata pelajaran akidah aklak karena nilai korelasi sangat signifikan adalah 0,000. Hasil ini menujukkan Ha diterima dan Ho di tolak. Sehingga semakin besar dukungan sosial orang tua semakin bagus prestasi belajar mata pelajaran akidah akhlak siswa MTsN 3 Sijunjung, karena hasil koefisiensi berdistibusi positif. Temuan dalam penelitian ini semakin besar dukungan sosial orang tua, akan dapat meningkatkan prestasi siswa dalam belajar mata pelajaran akidah akhlak.

\section{Keywords: Social Support, Learning achievement.}

Received: October 15, 2021; Revised: December 1, 2021; Accepted: December 16, 2021

\section{INTRODUCTION}

Indonesian's education goals have distinctive features, such as being devoted to God Almighty, having good character, being healthy spiritually and physically, having a high nationalism, and being responsible for his life in society (Nanda, 2019). So with this, education in Indonesia must shape people to become creative and active citizens because Indonesia is a rich country and can become a developed country following other developed countries if competent people manage it. Therefore education must receive special attention and be supported by various parties. In addition to the government and personnel in education, social support from parents in student education is very necessary because social support from parents will increase students' self-confidence so that these students can gain achievements in the education they are taking (Mufron, Ikhwan, Syuhada, \& Ridlowi, 2021).

Parents' social support also facilitates the child's path in the educational process in terms of the child's physical and psychological needs. Because children not only need material needs but children also need attention and affection from parents to encourage children in learning, so that it can increase children's motivation in education, and this makes it easier for children to achieve achievements because these children get the best support from their family (Siska, Solfema, \& Aini, 2018).

If a child in his education does not get the attention of parents, this will impact the child's learning process at school (Syam, Nurjan, \& Sumaryanti, 2021). For example, a parent is too focused on a career while unintentionally neglecting their children despite fulfilling their child's material needs. Thus, to get people's attention, sometimes children make mischief in school, without the children realizing that their misdeeds impact learning achievement or create learning disorders in the child. Therefore social support from parents is one of the things children need to achieve achievement (Nisa, 2018).

In education, we now see that many children in education experience a moral crisis, and it is contrary to what they have learned in the subject of akidah akhlak and lack of social support from parents, such as an article published by the National Republika newspaper entitled "cases of children violence jumped during the pandemic", on October 14, 2020 (Amrullah, 2020). "CNN Indonesia also published news of students 
committing suicide in Gowa, allegedly because they were pressured by studying online or PJJ, a high school student in the Gowa area, South Sulawesi, was desperate to drink poison, especially in the area that has inadequate internet access" published on Friday, October 23, 2020 (Wicaksono, 2020). On October 16, 2020, the case above showed a lack of social support from parents for children, and it was feared that this would be related to student learning outcomes.

The results of researcher observations at MTsN 3 Sijunjung on 14-18 September 2020 found several facts that some parents didn't care much about their children's education. During the pandemic, some parents encouraged their children to help them work instead of taking part in online learning so that it does not work optimally. Parents fully delegate their children's education to the school so that many student assignments are empty, and this affects the results of student learning achievement at school, so it is found that some children do not participate in online purchases and do not collect assignments that are given by a subject teacher at MTsN 3 Sijunjung.

Based on observations during distance learning at MTsN 3 Sijunjung, it can be seen that there is still a low attitude of respect for students during the teaching and learning activities. It is still found that students use disrespectful language when interacting during the teaching and learning process. This contradicts the material in the akidah akhlak lessons they have learned. In the daily tests of students at MTsN 3 Sijunjung, most of the students got scores below the KKM in akidah akhlak subjects.

Based on the news and the results of the observations above, it can be seen that the bottom picture of children needs social support from parents for their growth process, both material support and non-material support. Besides that, learning is a process from not knowing to know and what is less good becomes better. Therefore, the researcher is interested in researching "the relationship between parents 'social support and learning achievement in the subject of akidah akhlak in MTsN 3 Sijunjung students". Researchers intended to see the relationship between parents' social support and learning achievement in the subject of akidah akhlak in MTsN 3 Sijunjung students, whether the relationship is positive or negative through a quantitative approach.

\section{Theoretical Framework}

As the literature review, the researcher referred to a journal entitled "Parental Autonomy-support, Parental Control, Ses and Mathematics Achievement: A latent Profile Analysis." The journal was written by Meijia Shi and Cheng Yong Tan with ISSN 2150-2641 in 2020 published by Routledge. This study shows that control and autonomy that come from parents are two different things, and the profile of parents also affects mathematics achievement in children, children whose parents are entrepreneurs scored higher in math achievement than parents who use democracy/managing as a parenting style has an effect on student achievement. This research was conducted in Shenzhen, mainland China.

This study discusses parental support, and the journal in this study took the y variable mathematics achievement, while the researcher made the achievement variable in subjects into the y variable. The problem studied was to determine whether there was a relationship between the social support of parents' control and the profile of parents with student achievement in mathematics. The research used a quantitative approach while the researcher examined a relationship between parental social support and 
learning achievement in the subject of akidah akhlak at MTsN 3 Sijunjung without a parental profile (Shi \& Tan, 2021).

Rook expressed that social support is related to intrapersonal and the desire to protect individuals from stress (Rook \& Fisher, 1995). The presence of consent makes a person or this individual feel comfortable to create a sense of security and increase one's self-confidence for competence. Alhafid \& Nora also contribute their opinion that people who get social support will create a feeling that they are loved and appreciated in part of their social environment as well as feelings of feeling safe quoting in journals (Alhafid \& Nora, 2020).

According to Hil and Tyson, social support from parents significantly leads to positive development (Hill \& Tyson, 2009). Benson suggests that home-based parental social support is positively related to student achievement (Benson, Nwagbo, Ugwuanyi, \& Okeke, 2021). Based on the opinion of the experts above, it can be concluded that parental social support is the support provided by parents to their children to help their children face problems in life and provide support in the form of attention and affection for children, so that a sense of self-respect arises and feel loved by their parents, this social support can be in the form of physical or non-physical support. Parents' social support is also closely related to the psychological development of children.

According to Rook, social support comes from two sources accepted by an individual (Rook, 1987). First, social support from Artificial sources is social support planned for the primary needs of an individual, for example, in the form of social support that arises as a result of a disaster and as a result of this disaster, many people donate to victims affected by the disaster, and this is called artificial source. Natural sources are social support that arises because of automatic interactions with people around us. For example, social support arises because of blood relations or an incident such as a parent to a child and a husband to his wife. This social support appears to result from automatic or spontaneous interaction with an individual. Parents' social support for children includes Natural sources (Amroni, 2019).

Based on the opinion of Hause, there are four aspects of social support (House \& Khan, 1985). The first is emotional support, and this support is the support provided because an individual feels what other individuals are feeling, which is known as empathy so that the individual will feel safe, comfortable, and protected and feel that they can be heard. One example of this support is a mother who feels pain when she is sick. This pain arises because of a mother's empathy for her child. Second, appreciation support This support occurs because of a positive influence on individual achievement, thus giving birth to positive energies towards individuals who receive this social support. This support can be in the form of an individual's consent or expressions of encouragement or praise. For example, when a student gets a class winner, a teacher congratulates and praises the student.

The third is instrumental support. This support is to provide what an individual needs. For example, when a child enters a school, the parents provide the facilities needed by a child for school. The last one is informative support, and this support can be in the form of providing information or direction. It can also be called advice from an individual to another individual so that those who get this support can find solutions to the problems faced by that individual. 
Based on Hamalik opinion, learning is a process of an activity and is not a result or goal. In learning, this is remembering and includes experience, and it has a broader meaning (Hamalik, 2019). The result of this learning is mastery of the effects of the exercise and changes in behaviour. Slameto also expressed his opinion that learning is a process that a person goes through to change behaviour for the better, and it can also be formed due to interactions with the environment. If it is combined between achievement and learning, it can be concluded that this achievement was obtained from the learning process by students (Nasution, 2017).

The results of this learning evaluation will be a competition for students to achieve the highest score or the best results, so those who get low results will be motivated to beat those who have obtained high results. Those who get high results will try to maintain their performance so that there is no decline in the future or at the following study evaluation. Based on what is described above, educators and parents will do their best to shape children to have exemplary achievements (Izzaty, Ayriza, \& Setiawati, 2017). In terms of etymology, the word aqidah comes from Arabic, 'aqada-ya' qidu-aqdanaqidatan. The word aqdan has the meaning of knot, bond, agreement, and firmness, but once formed, the word aqidah has the meaning of faith. Etymologically, morality comes from the Arabic language jama', and the mufrod form is خلق which means character, behaviour, or tabi'at (Ilyas, 2016).

Based on the above discussion, it can be concluded that learning achievement in akidah akhlak is the result obtained by students after carrying out learning about akidah akhlak, using evaluation to measure the extent to which students understand the material that has been taught. The scope of the material discusses the faith in Islam and morals or manners in Islam to become a science used in everyday life (Anwar, 2021).

\section{METHOD}

The type of research was field research using a descriptive method with a quantitative approach. An illustrative way aimed to describe existing phenomena, either natural or human engineering, with the nature of the study using size, quantity, or frequency. It is supported by data obtained through field research, such as data collection from the object under investigation (Semiawan \& Roco, 2017).

In this study, the researcher used a correlational research type and in the research approach with a quantitative approach. Arikunto's opinion stated that a quantitative approach uses numbers, including data collection and interpretation (Arikunto, 2013). According to Creswell, through statistical procedures, quantitative research can be evaluated and analyzed as quoted in (Creswell, 2014);(Duli, 2019).

This research is a non-experimental or survey research design, a systematic empirical study in which the researcher cannot directly control the variables. Survey research seeks to explain in quantitative form the attitudes or opinions of research subjects by using a questionnaire as a method of collecting data and documents (Adiyanta, 2019).

The research was conducted using the survey method. Through the questionnaire as the primary research instrument, the survey conducted by the researcher was clarified using a measuring device. After that, learning achievement of the akidah akhlak subjects was obtained from the document of student learning outcomes in akidah. 
Morals of the school correlated with the relationship between one variable and the other variable were measured using SPSS product moment (Ikhwan, 2021).

In this study, the researcher did the investigation in MTsN 3 Sijunjung located in Jl. Diponegoro, Lubuak Tarok, Sijunjung West Sumatra 27533. It is one of the State Madrasas in the Sijunjung area of West Sumatra.

According to Danang, the questionnaire data collection technique is a data collection technique carried out by making statements to communicate with data sources. In this study, the questionnaire was used to collect data from the respondents (Sunyoto, 2016). The questionnaire contains statements about parents' social support for MTsN 3 Sijunjung students.

According to Sugiyono, Documentation was a way to get data from archives or documents or citing books (Sugiyono, 2013). In this case, the documents used by the researcher were documents of the moral values of students at MTsN 3 Sijunjung, as well as records regarding the profile of MTsN 3 Sijunjung school.

In this study, the researcher used two variables, the variable $X$ and social support for the parents of class VIII students of MTsN 3 Sijunjung. The data collection technique uses a questionnaire filled in by grade VIII students of MTsN 3 Sijunjung. The Y variable with the learning achievement variable in akidah akhlak subjects in class VIII students of MTsN 3 Sijunjung. With the technique of using documents or scores from the results of the VII grade students of MTsN 3 Sijunjung.

\section{RESULT AND DISCUSSION}

Parental Social Support Level

The basis of decision making for the level of learning achievement in akidah akhlak subjects is

$$
\begin{aligned}
& \mathrm{X} \min =26 \\
& \mathrm{X} \max =104 \\
& \mathrm{R}=104-26=26
\end{aligned}
$$

Table 1. Parental Social support Category

\begin{tabular}{ccc}
\hline Interval & Social support Category & Frequency \\
\hline $26-52$ & Low & 8 \\
\hline $53-78$ & Medium & 121 \\
\hline $79-104$ & High & 9 \\
\hline & Total & 138
\end{tabular}

Based on the 26 statements that have been shared in this study to 138 students. Researchers analyze, based on the results of the questionnaire that was distributed to 138 students, 8 students obtained results that getting low parental social support with a percentage of $6 \%$ getting a low category in parental social consent, in the moderate category the number of students who occupied this category was 121 people with a percentage range of $88 \%$. Students who get the high parental social support category occupy $6 \%$, with 9 students. 
Based on descriptive statistics, the social support of parents at MTsN 3 Sijunjung is at a moderate level. Divided into three categories of groups, low, medium, and high levels

Level of learning achievement in akidah akhlak subjects at MTsN 3 Sijunjung

$\mathrm{Xmin}=50$

$\mathrm{Xmax}=90$

$\mathrm{R}=90-50 / 3=14$

Table 2. Parental Social support Category at MTsN 3 Sijunjung

\begin{tabular}{ccc}
\hline Interval & Social support Category & Frequency \\
\hline $50-63$ & Low & 34 \\
\hline $64-77$ & Medium & 73 \\
\hline $78-90$ & High & 31 \\
\hline & Total & 138
\end{tabular}

Based on the learning achievement of morals at MTsN 3 Sijunjung with the number of respondents in this study were 138 respondents who were divided into three categories of the low, medium, and high. Students who were included in the low category of learning achievement in akidah akhlak subjects at MTsN 3 Sijunjung amounted to 34 people with a percentage of $25 \%$, students who are in the variety of learning achievement in akidah akhlak in the medium category are 73 people with a rate of $53 \%$ in the high class for learning achievement in akidah akhlak with 31 students, the percentage result is $22 \%$.

Based on the learning achievement of morals at MTsN 3 Sijunjung with the number of respondents in this study were 138 respondents who were divided into three categories of the low, medium, and high. Students who were included in the low category of learning achievement in akidah akhlak subjects at MTsN 3 Sijunjung amounted to 34 people with a percentage of $25 \%$, students who are in the variety of learning achievement in akidah akhlak in the medium category are 73 people with a rate of $53 \%$ in the high sort for learning achievement in akidah akhlak with 31 students, the percentage result is $22 \%$.

Table 3. One-Sample Kolmogorov-Smirnov Test

\begin{tabular}{llrr}
\hline & & $\begin{array}{r}\text { Parental social } \\
\text { support }\end{array}$ & $\begin{array}{c}\text { Learning } \\
\text { achievement }\end{array}$ \\
\hline N & Mean & 138 & 138 \\
Normal Parameters & Std. Deviation & 66,1667 & 69,8188 \\
Most Extreme Differences & Absolute & 8,76421 & 9,73011 \\
& Positive &, 075 &, 109 \\
& Negative &, 056 &, 097 \\
Kolmogorov-Smirnov Z & &,- 075 &,- 109 \\
Asymp. Sig. (2-tailed) & &, 880 & 1,279 \\
\hline a. Test distribution is Normal. & &, 421 &, 076 \\
b. Calculated from data. & & &
\end{tabular}


The basis for making conclusions or decisions from the results of the normality test is drawn from the following provisions:

1. If the significance value (Sig.) $>0.05$, the data in the study can be said to be expected so that it can continue to test the correlation.

2. If the significance value (Sig.) $<0.05$, the data in the study is declared abnormal, and it cannot be continued for the correlation test step.

Based on the table of normality test results, the results of parental social support with a Sig value of $0.421>0.05$ so that the parent social support variable at MTsN 3 Sijunjung is declared to have a normal distribution. The normality test results of the student learning achievement at MTsN 3 Sijunjung obtained results 0.076>0.05, so it can be concluded that the student learning achievement variable usually is distributed so that these two variables can be continued with a correlation test between the two variables above. The desire to do the correlations test is that the two research data must be normally distributed because the two data are tested and get the results that the data are typically distributed.

Table 4. Correlations

\begin{tabular}{llrr}
\hline & & $\begin{array}{c}\text { Parental social } \\
\text { support }\end{array}$ & \multicolumn{2}{c}{$\begin{array}{c}\text { Learning } \\
\text { achievement }\end{array}$} \\
\hline Parental social support & Pearson Correlation & 1 &, $428^{* *}$ \\
& Sig. (2-tailed) & 138 &, 000 \\
& $\mathrm{~N}$ &, $428^{* * *}$ & 138 \\
\hline Learning achievement & Pearson Correlation &, 000 & 1 \\
& Sig. (2-tailed) & 138 & 138 \\
& $\mathrm{~N}$ & &
\end{tabular}

Based on the person correlation analysis, there is a strong relationship based on the Sig. (2-tailed) 0.00, which is included in the correlation coefficient category, is very significant because it is in the significance range (Sig.) 0.01, which can be interpreted or translated that the correlation or difference is stated to be very significant. Analysis of the coefficients in the results of this study obtained results of 0.428 , which were positively distributed, and within this range of values, the correlation was at a moderate level.

\section{Analysis of Results}

Rook (1994) expressed his opinion that social support is related to intrapersonal and the desire to protect individuals from stress in the form of stress, with the presence of consent makes a person or this individual feel comfortable so that it will create a sense of security and increase one's self-confidence for competence. Emelda \& Kristina, 2018).

Tahir argued that social support is where a person feels that he is getting social help in the life he is going through (Tahir, 2015). He believes and feels that social support can be in the form of informative help or emotional support or in the actual state of family support to other families that can be supposed in real terms, it can be in various relationships, such as peers, parents to their children and so on. 
Detels \& Lee also expressed their opinion regarding parental social support. In this case, they divide it into positive and negative categories. The positive one is the support shown by parents in behaviour that leads to good things, contrary to social support from parents that is negative is behaviour that gets negative values and can direct children towards negative things (Detels \& Lee, 2017).

Based on the opinion of the experts above, it can be concluded that social support is essential for individuals to increase their self-confidence so that the individual can develop their potential well. The essential social support that individuals get is support from their closest people if an individual occupies the position of a child. The most important social support for individuals is social support from their parents.

In learning achievement results, it consists of achievement and learning. The term achievement in the Popular Scientific Dictionary is defined as the result achieved. According to Noehi Nasution, concluded that "learning in a broad sense can be interpreted as a process that allows the emergence or change of a behavior as a result of the formation of the main response, provided that the change or emergence of new behaviour is not caused by temporary changes for some reason" (Solichin, 2015).

According to Djamaroh, "achievement is the result of a learning business acbehaviourhich is expressed in the form, numbers, letters, or sentences which reflect the results achieved by each student" (Bahri, 2002). MTsN 3 Sijunjung, based on descriptive statistical analysis, got an average result of 69.8188 based on a predetermined interval range, that the learning achievement of akidah akhlak subjects at MTsN 3 Sijunjung was in the medium category. It is in the range 63 - 75 so that it can be decided that the learning achievement of akidah akhlak subjects at MTsN 3 Sijunjung is interpreted in a moderate level based on three levels of low, medium, and high.

The results of descriptive analysis research also get the results of the category level with the percentage, for the low level of learning achievement of the 138 respondents who were in the category of learning achievement levels in the subjects of akidah akhlak, 34 respondents with a percentage of $25 \%$, in the type of moderate level 73 respondents who got the results of learning achievement in akidah akhlak subjects in the medium class with a percentage of 53\%. The highest category level is 31 respondents who get learning achievement results in the high category.

\section{Parental Social Support Relationship}

Based on the explanation of theories and opinions of experts, social support is crucial for children. A child feels that he is loved, appreciated, and it instils confidence in a child to explore their potentials. This social support is an encouragement from outside the individual to develop their potential.

Different studies reveal a relationship between parental involvement and academic achievement. Parental involvement refers to situations where parents are directly involved in their children's education. However, parental involvement has too many dimensions, such as perceptions of support, organization, interest in the educational process, expectations, school relationships, time to support homework based on research from one of the previous journals (Panaoura, 2021).

Based on the person correlation analysis, the Sig has a solid relationship. (2-tailed) 0.00 , which is included in the correlation coefficient category, is very significant because it is in the range of significance (Sig.) $<0.01$. It can be interpreted that the 
correlation or difference is stated to be very significant. Analysis of the coefficients in the results of this study obtained results of 0.428 , which were positively distributed, and within this range of values, the correlation was at a moderate level.

If the significance value (Sig.) $<0.01$ can be interpreted or translated, the correlation or difference is stated to be very significant. While the results of this study the value of Sig. (2-tailed) 0.00 so that to make a decision can state that the relationship between parents' social support and learning achievement in akidah akhlak subjects is in a very significant correlation stage. The result of the coefficient in this study is 0.428 based on the opinion of Sugiyono (2013) the range of intervals from 0.40 to 0.599 can be interpreted as the level of the relationship in this range is moderate, the coefficient results of this study are positively distributed so that from this study it can be concluded that the higher the social support of people parents at MTsN 3 Sijunjung, the higher student achievement in akidah akhlak subjects at MTsN 3 Sijunjung.

\section{CONCLUSION}

Based on the descriptive statistical analysis, the social support of parents at MTsN 3 Sijunjung is in a moderate stage. Both from the overall results and the results per questionnaire category. Students who get social support results from parents at low levels are eight people, at moderate levels are 121 people, and at high levels are nine people. The average value is 66.1667, in the medium interval range between $26-78$. The total number of respondents is 138 .

Based on the descriptive statistical analysis, the learning achievement of akidah akhlak at MTsN 3 Sijunjung is at a moderate level of learning achievement with an average result of 68.8188 based on the interval is in the medium category. The value range is $63-75$. The results of the analysis of students who get learning achievement in akidah akhlak subjects, low level 34 people, medium level 73 and high 31 people with a total number of 138 respondents

Based on the results, the significance (Sig.) $<0.01$ belongs to the very significant correlation. The coefficient in this study is 0.428 , with a favourable distribution. It can be interpreted that the higher the social support of the parents, the higher the learning achievement of students' subjects.

\section{REFERENCES}

[1] Adiyanta, F. C. S. (2019). Hukum dan Studi Penelitian Empiris: Penggunaan Metode Survey sebagai Instrumen Penelitian Hukum Empiris. Administrative Law and Governance Journal, 2(4), 697-709.

[2] Alhafid, A. F., \& Nora, D. (2020). Kontribusi Dukungan Sosial Orang Tua dan Peran Teman Sebaya Terhadap Hasil Belajar Sosiologi Siswa kelas X dan XI di SMA Negeri 2 Bengkulu Selatan. SIKOLA Jurnal Kajian Pendidikan Dan Pembelajaran, 1(4).

[3] Amroni, A. (2019). Hubungan Antara Dukungan Sosial Orang Tua dengan Motivasi Mengikuti Ekstrakurikuler Palang Merah Remaja di MAN 1 lamongan. Universitas Islam Negeri Maulana Malik Ibrahim Malang.

[4] Amrullah, A. (2020). Kemensos: Kasus Kekerasan Anak Melonjak. 
[5] Anwar, S. (2021). Pendidikan Karakter: Kajian Perspektif Tafsir fi Zilalil Qur'an. Tulungagung: STAI Muhammadiyah Tulungagung.

[6] Arikunto, S. (2013). Prosedur Penelitian. Jakarta: Rineka Cipta.

[7] Bahri, D. S. (2002). Strategi Belajar Mengajar. Jakarta: Rineka Cipta.

[8] Benson, O. o., Nwagbo, C. R., Ugwuanyi, C. s., \& Okeke, C. i. O. (2021). Improving Students' Achievement and Retention in Biology using Flipped Classroom and Powerpoint Instructional Approaches: Implication for Physics Teaching. International Journal of Psychosocial Rehabilitation, 25(2), 1470114714.

[9] Creswell, J. W. (2014). Risearch Design: Pendekatan Kualitatif, Kuantitatif, dan Mixed. Yogyakarta: Gadjah Mada University Press.

[10] Duli, N. (2019). Metode Penelitian Kuantitatif: Beberapa dasar untuk menulis Skripsi \& Analisis data dengan SPSS. Yogyakarta: Deepublish Publisher.

[11] Hamalik, O. (2019). Dasar-dasar pengembangan kurikulum. Bandung: PT Remaja Rosdakarya.

[12] Hill, N. E., \& Tyson, D. F. (2009). Parental Involment In Middle School: Metaanalytic Assesment Of The Strategies That Promote Achievement. Develomental Psychology, 45(3), Parental Involment In Middle School: Metaanalytic.

[13] House, J., \& Khan, R. L. (1985). Measures and Concept of Social Support. London: Academic Press Inc.

[14] Ikhwan, A. (2021). Metode Penelitian Dasar (Mengenal Model Penelitian dan Sistematikanya). Tulungagung: STAI Muhammadiyah Tulungagung.

[15] Ilyas, Y. (2016). Kuliah Aqidah Islam. Yogyakarta: LPPI.

[16] Izzaty, R. E., Ayriza, Y., \& Setiawati, F. A. (2017). Prediktor Prestasi Belajar Siswa Kelas 1 Sekolah Dasar. Jurnal Psikologi, 44(2), 153 - 164.

[17] Mufron, A., Ikhwan, A., Syuhada, M., \& Ridlowi, A. (2021). Optimizing the Organizational Structure in Transforming Human Resources Who Can Manage Work Stress With a Religious Culture. European Journal of Molecular \& Clinical Medicine, 8(3), 1110-1126.

[18] Nanda, A. S. (2019). Supervisi Pendidikan dalam Mewujudkan Tujuan Nasional Pendidikan dan Meningkatkan Mutu Pendidikan. In INA-Rxiv Papers.

[19] Nasution, M. K. (2017). Penggunaan Metode Pembelajaran Dalam Peningkatan Hasil Belajar Siswa. STUDIA DIDAKTIKA: Jurnal Ilmiah Bidang Pendidikan, 11(1), 9-16.

[20] Nisa, A. (2018). Analisis Kenakalan Siswa dan implikasinya Terhadap Layanan Bimbingan Konseling. Jurnal EDUKASI (Media Kajian Bimbingan Konseling), 4(2), 102-124.

[21] Panaoura, R. (2021). Parental Involvement in Children's Mathematics Learning Before and During the Period of the COVID-19. Social Education Research, 2(1), $65-74$.

[22] Rook, D. W. (1987). The Buying Impulse. Journal Of Consumer Research, 14(2), 
193 Al-Hayat: Journal of Islamic Education (AJIE)

e-ISSN: 2599-3046 (online) | Volume 5, Issue 2 | July-December 2021

p-ISSN: $2657-1781$ (print)

198-199.

[23] Rook, D. W., \& Fisher, R. J. (1995). Normative Influences on Impulsive Buying Behavior. JOURNAL OF CONSUMER RESEARCH.

[24] Semiawan, C. R., \& Roco, J. (2017). Metode Penelitian Kuantitatif. Jakarta: Pelita Harapan.

[25] Shi, M., \& Tan, C. Y. (2021). Parental Autonomy-Support, Parental Control, SES, and Mathematics Achievement: A Latent Profile Analysis. Journal of Research in Childhood Education, 35(4).

[26] Siska, M., Solfema, \& Aini, W. (2018). Hubungan Dukungan Sosial Orang Tua Dengan Hasil Belajar Santri Di Mda Nurul Haq Nagari Cubadak Kecamatan Dua Koto Kabupaten Pasaman. SPEKTRUM Jurnal Pendidikan Luar Sekolah (PLS), 1(2), 138-244.

[27] Solichin, A. W. (2015). Analisis Kebijakan Dari Formulasi Ke Penyusunan Modelmodel Implementasi Kebijakan Publik. Jakarta: PT Bumi Aksara.

[28] Sugiyono. (2013). Metode Penelitian Pendidikan. Bandung: Alfabeta.

[29] Sunyoto, D. (2016). Metodologi Penelitian Akuntansi. Bandung: PT Refika Aditama Anggota Ikapi.

[30] Syam, A. R., Nurjan, S., \& Sumaryanti, L. (2021). Analysis of development of gifted students in elementary school. KONSELI: Jurnal Bimbingan Dan Konseling (E-Journal), 8(1), 91-98.

[31] Tahir, A. (2015). Kebijakan Publik \& Transparansi Penyelenggaran Pemerintah Daerah. Bandung: Alfa Beta.

[32] Wicaksono, A. (2020). Siswa bunuh diri di Gowa, KPPI minta guru diperiksa. 